\title{
DEPENDENCE OF THE INDIGESTIBILITY OF WOOL PROTEIN UPON ITS POLYMERIC STRUCTURE
}

\author{
By Walton B. Geiger and Milton Harris ${ }^{1}$
}

\begin{abstract}
The resistance of wool to digestion by enzymes is probably due to a unique structure, consisting of peptide chains joined by disulfide cross-links to form a three-dimensional polymeric network of extremely high molecular weight. This conclusion is substantiated by a study of a series of derived wool proteins similar in composition but expected to differ in molecular weight. The proteins were prepared by first "depolymerizing" wool by reducing its disulfide cross-links to sulfhydryl groups, then making a series of solutions of this protein of widely varying cencentration, and finally rebuilding the disulfide cross-links by reoxidation.

An investigation of the rates of digestion by pepsin of a series of such proteins showed that those preparations expected to be of low molecular weight were rapidly digested, whereas those expected to be of greatest molecular weight were almost as resistant to digestion as untreated wool.
\end{abstract}

\section{CONTENTS}

I. Introduction

II. Experimental procedure

1. Preparation of the reduced wool protein

2. Preparation of the reoxidized proteins $\ldots \ldots \ldots \ldots$

3. Determination of the digestibilities of the reoxidized proteins - $_{-} 274$

III. Results and discussion

IV. References

\section{INTRODUCTION}

The keratins, which are a group of fibrous proteins found in the epidermis and its appendages, are characterized by their insolubility in the usual protein solvents, such as dilute solutions of acids, bases, and salts, and by indigestibility by proteolytic enzymes [1]. ${ }^{2}$ The member of the keratin group that has been most thoroughly studied is wool, and on the basis of earlier work on the material (reriewed elsewhere [2, 3]), it seems that these characteristic properties are dependent upon the presence of disulfide cross-linkages between the polypeptide chains of the protein. The present paper reports additional experiments directed toward the further testing of this hypothesis.

A wool fiber consists of two principal regions, root and shaft. The shaft alone possesses the properties typical of keratins, whereas the root is soft and is composed of protein that is largely soluble in dilute alkali and readily digested by proteolytic enzymes. The process by

1 Research Associates at the National Bureau of Standards, representing the Textile Foundation.

2 Figures in brackets indicate the literature references at the end of this paper. 
which the protein in the root portion of the fiber, called "prekeratin", is transformed to the keratin of the shaft is termed "keratinization." Since much of the sulfur of prekeratin appears to be present as sulfhydryl groups, and in keratin almost entirely as disulfide groups, it has been suggested that keratinization involves an oxidative process and that prekeratin is transformed to keratin when the root portion becomes shaft $[4,5]$.

Evidence that the transformation of sulfhydryl groups to disulfide groups is not in itself sufficient to account for the properties of the keratin has been obtained by Goddard and Michaelis [6]. These authors reported that a reduced wool protein, prepared by dissolving wool in an alkaline solution of sodium thioglycolate, was digested by proteolytic enzymes, but that a reoxidized protein, obtained by dissolving the reduced protein in alkali and treating it with an oxidizing agent, was likewise digested. Under the conditions of their experiments, however, the fibrous structure of the wool was destroyed and the products obtained were amorphous powders. More recently, it has been observed in this laboratory that wool fibers may be reduced with thioglycolic acid at $\mathrm{pH}$ values below 7 without destroying their fibrous structure [3]; but whereas the reduced fibers are readily digested by enzymes, they differ from the products obtained by Goddard and Michaelis in becoming as indigestible as the original wool on reoxidation.

A possible basis for the difference in the behavior of the two products has already been indicated [3]. It was suggested that the resistance of wool, and of the reoxidized fibers, to digestion was caused, not by the chemical nature of the groups involved, but by the existence of a compact three-dimensional structure, which is present in the reoxidized fibers, but not, at least to the same degree, in the amorphous reoxidized protein. This suggestion resulted from the following considerations. Reduced wool presumably consists of polypeptide chains containing cysteine residues, and in the sense of Carothers' definition [7], each of these chains is a linear polymer bearing functional groups (sulfhydryl) capable of reacting with each other to yield a three-dimensional polymer. Oxidation of the reduced wool could result in the formation of cross-linkages between different polypeptide chains through conversion of sulfhydryl to disulfide groups and thus cause the formation of polymers of high molecular weight. The formation of such polymers is favored when the concentration of the reactant is high; at lower concentrations, lower degrees of polymerization are to be expected. This is the so-called "dilution principle" $[8,9]$, which indicates that reactions of low order, yielding monomers (or in certain cases, dimers or other low polymers), may be expected at extreme dilutions, and higher-order reactions; yiclding many-membered polymers, in more concentrated solutions. The application of this principle to the present problem suggested that the formation of disulfide cross-linkages between different polypeptide chains should be favored when reduced wool fibers are reoxidized, because in the fiber the concentration of reactant (reduced protein) is extremely high. Reoxidation by the method of Goddard and Michaelis, in which a solution of reduced wool protein is treated with an oxidizing agent, should result in a lower degree of polymerization, since the formation of disulfide cross-links between different parts of single folded chains as well as between different chains may be expected. 
A similar explanation has been suggested by Strain and Linderstrøm-Lang [10] for the formation of insoluble compounds during oxygenation of papain digests of wool. These authors found that when concentrated solutions of partly digested reduced wool protein were aerated, material insoluble in 12- to 13-percent trichloroacetic acid was formed, but that aeration of similar, but dilute, solutions did not lead to such products.

The present paper describes an effort to test this hypothesis further. Accordingly, reduced wool protein was prepared [6], a series of solutions of this protein of widely different concentrations was made, the reduced protein was reoxidized, and the digestibility and solubility of the products were determined.

\section{EXPERIMENTAL PROCEDURE}

\section{PREPARATION OF THE REDUCED WOOL PROTEIN}

The reduced wool protein was prepared by a procedure similar to that of Goddard and Michaelis [6], except that acetic, instead of hydrochloric, acid was used for precipitating the protein, and alcohol and ether, instead of acetone and ether, for drying it. Two-hundred grams of wool was dissolved by warming at about $40^{\circ} \mathrm{C}$ in 4 liters of a $0.5 M$ solution of sodium thioglycolate containing sufficient excess alkali to bring the $\mathrm{pH}$ to about 12 . A small amount of undissolved material was filtered off, and the filtrate brought to about $\mathrm{pH} 4$ with acetic acid. The voluminous, white, curdy precipitate which formed was then filtered off, washed with water until free of thioglycolic acid, then with alcohol, and finally with ether. The precipitated protein was dried over concentrated sulfuric acid in an atmosphere of nitrogen at a pressure of $2 \mathrm{~mm}$ of mercury. The dry product weighed $85 \mathrm{~g}$. No extensive change in composition had taken place, since the original wool contained 16.50 percent of nitrogen and 3.47 percent of sulfur, and the reduced protein contained 16.55 percent of nitrogen and 3.40 percent of sulfur.

\section{PREPARATION OF THE REOXIDIZED PROTEINS}

Three of the four reoxidized samples were prepared by dissolving samples of reduced wool protein weighing $5 \mathrm{~g}$ in different volumes of $0.1 M$ carbonate buffer at $\mathrm{pH} 9$ [11] and passing oxygen through the solution at $20^{\circ} \mathrm{C}$ until a positive nitroprusside reaction was no longer obtained. The concentrations of protein were $2,0.2$, and 0.05 percent. After the reaction was complete, the reoxidized proteins were precipitated by bringing the solutions to $\mathrm{pH} 4$ with acetic acid. The precipitates were filtered off, washed with distilled water, alcohol, and ether, and dried in vacuum over concentrated sulfuric acid. The fourth sample was not dissolved, but was reoxidized while still a powder by suspending it in distilled water (in which it was not measurably soluble) and bubbling oxygen through this suspension until the particles of protein no longer gave a positive nitroprusside reaction. The analytical data are given in table 1. 
TABLE 1.-Analysis of the reoxidized proteins

\begin{tabular}{|c|c|c|c|c|}
\hline Method of preparation & Yield & Nitrogen & Sulfur & Cystine \\
\hline Untreated wool_ & $g$ & $\begin{array}{l}\text { Percent } \\
\quad 16.50\end{array}$ & $\begin{array}{c}\text { Percent } \\
3.47\end{array}$ & $\begin{array}{l}\text { Percent } \\
10.5\end{array}$ \\
\hline Suspension & 5.0 & 16.52 & 3.30 & 9.4 \\
\hline $\begin{array}{l}20 \text {-percent solution } \\
0.2 \text {-percent solution }\end{array}$ & 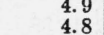 & $\begin{array}{l}16.55 \\
16.55\end{array}$ & $\begin{array}{l}3.38 \\
3.26\end{array}$ & $\begin{array}{l}9.3 \\
9.5\end{array}$ \\
\hline 0.05 -percent solution & 4.6 & 16.53 & 3.15 & \\
\hline
\end{tabular}

\section{DETERMINATION OF THE DIGESTIBILITIES OF THE REOXIDIZED PROTEINS}

The reoxidized proteins were comminuted in a Wiley mill, and the material that passed through a 20 -mesh, but not through a $40-$ mesh, sieve was used. Portions weighing $0.5 \mathrm{~g}$ were suspended in $50 \mathrm{ml}$ of a $0.2 M$ solution of potassium chloride, which was adjusted to $\mathrm{pH}$ 1.1 by the addition of hydrochloric acid, and which contained $20 \mathrm{mg}$ of pepsin. ${ }^{3}$ The suspensions were gently shaken for 24 hours, at $25^{\circ} \mathrm{C}$. The extent of digestion was measured by determining the amount of "nonprotein" nitrogen (nitrogenous material soluble in dilute trichloroacetic acid) in samples obtained by centrifuging the suspensions and removing aliquots of the supernatant solutions. To do this, each aliquot was added to five times its volume of a 3-percent solution of trichloroacetic acid ${ }^{4}$ and the mixture was heated to $80^{\circ} \mathrm{C}$ for 5 minutes, cooled, and filtered immediately. A measured portion of the filtrate was analyzed for nitrogen by the micro-Kjeldahl procedure of Clark [13].

Control experiments carried out in a similar manner, but in the absence of enzyme, showed that under these conditions no measurable amount of nitrogen soluble in the trichloroacetic acid was liberated from any of the samples, whereas other experiments showed that no measurable nonprotein nitrogen appeared in solutions of the enzyme in the absence of the proteins.

The rate of digestion was also estimated from the total dissolved nitrogenous material, although this method was found to be less useful than that described above. Control experiments similar to those described in the preceding paragraph showed that the total dissolved nitrogen increased on shaking the proteins with the acidic solutions. In these experiments two samples of each of the reoxidized proteins were shaken with the buffer solution alone for 24 hours. The enzyme was then added to one of each pair of suspensions, and all were shaken for 24 hours longer. The total soluble nitrogen was determined by centrifuging the suspensions, removing aliquots, and analyzing them directly for nitrogen [13]. The relative amounts of protein, buffer solution, and enzyme were the same as in the first series of experiments, and the results have been corrected for the nitrogen in the enzyme.

\section{RESULTS AND DISCUSSION}

A consistent relationship was found to exist between the concentration of a protein during reoxidation and the digestibility of the reoxidized material. Rapid digestion of the proteins prepared in the

\footnotetext{
${ }^{3}$ From Fairchild Bros. \& Foster, New York City, 1:3,000.

1 The final concentration, 2.5 percent, is that recommended by Hiller and Van Slyke [12] for separating proteins from their partly digested fragments.
} 
more dilute solutions took place, whereas proteins prepared at higher concentrations were digested more slowly. This is clearly apparent from the curves in figure 1, where the criterion of digestion was the production of "nonprotein" nitrogen.

The three proteins reoxidized in dilute solution were rapidly digested, and the greater the dilution, the more rapid was the digestion. The fourth protein, prepared by reoxidizing the powdered reduced material in aqueous suspension, showed a resistance to digestion. resembling that of untreated wool. Likewise, visual examination

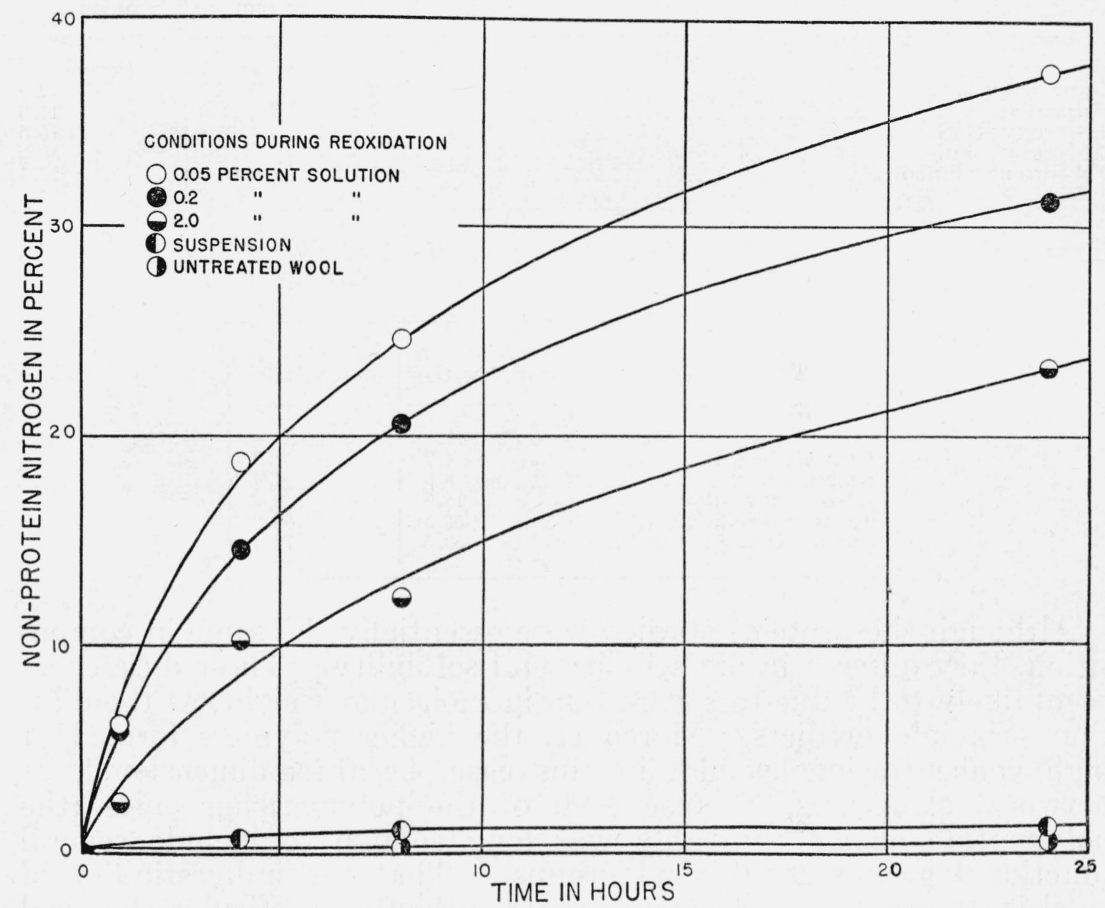

FIGURE 1.-Percentage of the nitrogen of the proteins present as nonprotein nitrogen at the indicated times.

demonstrated that the proteins reoxidized in dilute solution were largely dissolved by the enzyme, whereas the others seemed little changed in amount. Since the protein prepared under the conditions of highest concentration was almost as resistant to digestion as untreated wool, it appears that any secondary changes which may have occurred during reduction in the strongly alkaline solutions, such as loss of amide groups or hydrolysis of peptide bonds, did not affect the results markedly.

The results based on total soluble nitrogenous materials, recorded in table 2, lead to a similar conclusion. Although the data in this table indicate that equilibrium had not been reached in 24 hours, considerably more soluble nitrogen was produced during the second 24-hour period in the presence of enzyme than in its absence.

A similar trend also appears in the solubilities of the different wool preparations. The data recorded in table 3 show that the protein 
prepared at the highest concentration was nearly as insoluble as the original wool, whereas those samples prepared in dilute solution dissolved more readily.

TABLE 2.-Total soluble nitrogenous materials liberated from the proteins in the presence and in the absence of enzyme

\begin{tabular}{|c|c|c|c|}
\hline \multirow{2}{*}{ Method of preparation } & \multirow{2}{*}{$\begin{array}{l}\text { Total soluble } \\
\text { nitrogen after } \\
\text { first } 24 \text { hours- } \\
\text { No enzyme } \\
\text { present }\end{array}$} & \multicolumn{2}{|c|}{$\begin{array}{l}\text { Total soluble nitrogen after } \\
\text { second } 24 \text { hours }\end{array}$} \\
\hline & & $\begin{array}{l}\text { No enzyme } \\
\text { present }\end{array}$ & $\begin{array}{l}\text { Enzyme } \\
\text { present }\end{array}$ \\
\hline $\begin{array}{l}\text { Untreated wool } \\
\text { Suspension } \\
2.0 \text {-percent solution } \\
0.2 \text {-percent solution } \\
0.05 \text {-percent solution }\end{array}$ & $\begin{array}{r}\text { Percent } \\
0.2 \\
.7 \\
10.4 \\
13.5 \\
49.1\end{array}$ & $\begin{array}{r}\text { Percent } \\
0.3 \\
1.0 \\
12.8 \\
27.4 \\
60.6\end{array}$ & $\begin{array}{r}\text { Percent } \\
2.9 \\
11.3 \\
75.5 \\
80.0 \\
92.1\end{array}$ \\
\hline
\end{tabular}

$\mathrm{T}_{\mathrm{ABLE}}$ 3.-The extent to which the proteins were dissolved after 1 hour at $65^{\circ} \mathrm{C}$ by 100 times their weight of $0.01 \mathrm{~N} \mathrm{NaOH}$ or of $0.1 \mathrm{~N} \mathrm{HCl}$

\begin{tabular}{|c|c|c|}
\hline Method of preparation & $\begin{array}{l}\text { Solubility in } \\
0.01 N \mathrm{NaOH}\end{array}$ & $\begin{array}{l}\text { Solubility in } \\
0.1 \mathrm{~N} \mathrm{H} \mathrm{Cl}\end{array}$ \\
\hline $\begin{array}{l}\text { Untreated wool } \\
\text { Suspension } \\
2.0 \text {-percent solution } \\
0.2 \text {-percent solution } \\
0.05 \text {-percent solution }\end{array}$ & $\begin{array}{r}\text { Percent } \\
4.7 \\
8.9 \\
15.3 \\
55.5 \\
59.5\end{array}$ & $\begin{array}{r}\text { Percent } \\
1.3 \\
1.4 \\
8.2 \\
69.0 \\
78.5\end{array}$ \\
\hline
\end{tabular}

Although the proteins studied were essentially the same in composition, they differed in digestibility and solubility. These differences seem likely to be due to a variation in molecular weight, as the dilution principle predicts. Moreover, the higher polymers formed at high concentrations would, in this case, be three-dimensional, or network, structures, because each of the polymerizing units (the polypeptide chains) probably was long enough to include several functional groups (sulfhydryl groups). That the indigestibility of wool is due to structural factors, rather than to particular chemical linkages, has been suggested by Goddard and Michaelis [6] and has been further supported by recent work in this laboratory [3]. It was observed that wool fibers were digestible after the disulfide cross-links had been broken (without destroying the fibrous structure of the wool) and that indigestibility was restored by rebuilding cross-links, either by reoxidizing the sulfhydryl groups to disulfide groups or by transforming them to bis-thioether (-S- $\left(\mathrm{CH}_{2}\right)_{n}$-S-) groups by reaction with an alkyl dihalide.

A three-dimensional structure could lead to indigestibility in either of two conceivable ways. First, the proteins of high molecular weight show great insolubility (a typical characteristic of three-dimensional polymers), and an undissolved protein may be less readily attacked than one in solution. Second, a three-dimensional network of high molecular weight would have fewer of its peptide bonds at or near its surface, and those within may be comparatively less accessible to the enzyme, since molecules of pepsin are very large [14]. The present data do not, however, permit one to distinguish between these possibilities. 


\section{REFERENCES}

[1] R. J. Block, in C. L. A. Schmidt's Chemistry of the Amino Acids and Proteins, p. 278 (Charles C. Thomas, Springfield, Ill., 1938).

[2] W. I. Patterson, W. B. Geiger, L. R. Mizell, and M. Harris, J. Research NBS 27, 89 (1941) RP1405.

[3] W. B. Geiger, W. I. Patterson, L. R. Mizell, and M. Harris, J. Research NBS 27,459 (1941) RP1433.

[4] C. W. Hock, R. C. Ramsay, and M. Harris J. Research NBS ₹7, 181 (1941) RP1412.

[5] A. Kuntzel, G. Vago, and A. Seitz, Collegium 55 (1932).

[6] D. R. Goodard, and L. Michaelis, J. Biol. Chem. 106, 605 (1934); 112, 361 (1935).

[7] W. H. Carothers, Chem. Rev. 8, 353 (1931).

[8] P. Ruggli, Liebigs Ann. Chem. 392, 92 (1912).

[9] G. Salomon, Trans. Faraday Soc. 32, $153(1936)$.

[10] H. H. Strain, and K. Linderstrøm-Lang, Enzymologia 7, 241 (1939).

[11] H. Menzel, Z. physik. Chem. 100, 276 (1921).

[12] E. Hiller and D. D. Van Slyke, J. Biol. Chem. 53, 253 (1939).

[13] E. P. Clark, J. Assoc. Official Agr. Chem. 24, 641 (1941).

[14] T. Svedberg, Proe. Roy. Soc. (London) [B] 127, 1 (1939).

Washington, June 2, 1942. 